\title{
THE ANALYSIS OF THE RELATIONSHIP BETWEEN MARKETING STRATEGIES AND THE PERFORMANCE OF SMALL AND MEDIUM SIZED BUSINESSES IN ROMANIA
}

\author{
Carmen Adina Paştiu ${ }^{1}$ \\ Maria Mureşan ${ }^{2}$
}

\begin{abstract}
In this current study our aim was to analyze the marketing tactics, namely the strategic planning, market segmentation, correlation between the marketing activities and the firms' performances, as well. In this context, we intended to examine both the marketing practices and the associations between practices and performance. The marketing policy implies all the main aspects of the processes concerning the supply, dispatch, research-development and supervision of products consumption behavior. Its realization is being done by the marketing strategy.
\end{abstract}

KEYWORDS: small and medium sized firms; marketing strategy; performance; market segmentation

JEL CODES: M31

\section{Background}

The marketing policy implies all the main aspects of the processes concerning the supply, dispatch, research-development and supervision of products consumption behavior. Its realization is being done by the marketing strategy.

The firm strategy represents the core of the major actions direction. The component elements of the marketing strategy are being developed in the firm economic activity from the shoes industry by the aid of marketing tactics.

Starting with the 1960 s there has been allowed a great importance to planning concept as a method of dealing with the profound changes of the business environment. Ringbakk in 1971 and Ansoff in 1977 have been proved that the planning systems occurred as result of the evolution of the static ${ }^{3}$ systems, integrated in the management structures of the 1950s and 1960s, as well. The main weakness of this is that it is based on extrapolating. Gradually the strategic planning has appeared and therefore, the need for defining and clarifying of the business strategic unit occurred. The next stage has been the portfolio strategic management and the complex systems of strategic planning appeared; here the business environment takes an important role.

Luck and $\mathrm{O}^{\prime} \mathrm{Ferrel}^{4}$ suggest a simple definition of the strategy: the fundamental scheme for objectives achieving, and Weitz and Wensley, ${ }^{5}$ are aware of the following aspect: "It is the firm which determines the efforts placement, which the markets and markets segments are, and what kind of products they intend to commercialize".

Andrews ${ }^{6}$ considers as important the definition of the organization nature and the integration of the developed activities.

One can not speak about the strategic marketing without thinking to it own purpose, respectively, to the contribution at decision making. The specialized marketing manager

\footnotetext{
${ }^{1}$ University 1 Decembrie 1918 of Alba Iulia, România

${ }^{2}$ University 1 Decembrie 1918 of Alba Iulia, România

${ }^{3}$ Mc Donald , M.H.B., 1998. Marketing strategic , Ed. Codecs, Bucureşti, p. 43.

${ }^{4}$ Luck, D.,J., O'Ferrel, C., 1979. Marketing strategy and plans, Ed. Cliffs Prentice - Hall, Englewood.

${ }^{5}$ Weitz, S. ,Wensley, R., 1984. Strategic marketing, Kent Publishing, Boston.

${ }^{6}$ Andrews, K., 1984. Corporate Strategy: the essential intangibles', Mc Kinsey Quartely.
} 
understands the environment forces, the way the performance is influenced and finds the ways of determining the firm performance.

In the paper called "Competitive Advantage: creating and sustaining superior performance" M. Porter ${ }^{7}$ discusses about the importance of time series analysis. This type of analysis divides the firm's activities of performance and the available resources into a small number of important strategic categories.

\section{Is the strategic planning a necessity?}

Despite the small number of empirical studies, the majority of the specialized studies sustain that marketing planning is highly necessary, among these ${ }^{8}$ being Tiles (1969), Dodge (1970) and Davidson (1972). These authors consider the marketing planning a universal hub for solving the commercial planning, but the evidences are very few in these cases.

A study that highlighted the importance of marketing planning has been realized by Thompson $^{9}$ (in 1962); he affirms that, analyzing 20 big American companies for a period of three years, firms that prepared plans on needs, probable developments and even uncertain events, have registered better results than the companies kept unprepared enough for the changes occurred within markets, products and action methods.

The study carried out at Cranfield, during eight years ${ }^{10}$, on industrial goods exporting companies analyzed the modality in which they accomplish the marketing strategy. Many of the analyzed companies consider that the importance of the planning systems is not much higher than that of prognoses and budgets. These give an impulse and a direction to approaching the business current operational problems - aspect defined by the management literature as "the tunnel vision".

A study made by Leighton ${ }^{11}$ (in 1966) on 400 firms from the SUA, has showed that there is a correlation between firms with the highest development rate and those using planning systematic procedures.

Ansoff and Thune \& House ${ }^{12}$ used standard financial indicators as the capital/debt report in order to determine the effect of marketing planning on the firm's results. The success they enjoyed in the past was often the result of a certain easy purchase of products, and in their economic flourishing periods firms had to solve their operational problems. Planning for the following period didn't seem necessary. But still, in the recent years, more companies have difficulties as result of planning lack, and they began to be aware of the fact that their future survival and success are conditioned by careful planning and marketing preparation, as well.

\section{Research methodology \\ I. Research aims}

$O_{1} \quad$ Making a diagnosis on the current stage of using the marketing strategic planning in the small and medium sized companies and their future tendencies.

$\mathrm{O}_{2} \quad$ Analysis of the managers from the shoes industry concerning:

口 $\mathrm{O}_{2.1}$ the need for marketing planning

a $\mathrm{O}_{2.2}$ using the marketing strategy

- $\mathrm{O}_{2.3}$ using the strategic planning

- $\mathrm{O}_{2.4}$ areas of strategic planning

口 $\mathrm{O}_{2.5}$ analysis of market research usage

口 $\mathrm{O}_{2.6}$ analysis of marketing activity control

\footnotetext{
${ }^{7}$ Porter, M., 1985. Competitive advantage ; creating and sustaining superior performance, Free Press, New York.

${ }^{8}$ Mc Donald , M.H.B., 1998. Marketing strategic , Editura Codecs, Bucureşti, p. 44.

${ }^{9}$ Thompson, S., 1962. How Companies Plan, AMA Research Study, Nr. 54.

${ }^{10}$ Mc Donald, M.H.B., 1998. op. cit., p. 141.

${ }^{11}$ Leight D.S.R., 1966. International Marketing: Text and Cases, McGraw Hill, New York.

12 Thune, S., House, R., 1970. Where Long Range Planning Pays Off, Business Horizons, Vol.13, Nr.4, pp.81-87.
} 
The hypotheses established have been the following ones:

- $\mathrm{H}_{01}$ : The majority of the managers of small and medium sized companies do not consider that marketing planning is essential.

- $\mathrm{H}_{02}$ : Managers do not use planning at the market segment level.

- $\mathrm{H}_{03}$ : Managers do not formulate marketing strategies.

\section{Data Collection}

To examine the marketing practice-firm performance relationship, we chose to focus on small and medium sized firms from Transylvania, România.

The sampling frame consisted of all firms listed in the Statistic Guides from Transylvania, România. The sample was drawn using a stratified random sampling technique.

Each list had an equal number of firms selected from it, and all respondents within the individual area were selected on the basis of proportional representation. In this respect, we can assure that each county has been equally represented.

The data were collected using an online survey. The targeted firms initially received a letter of invitation to participate in the study. The invitation was directed to the general manager of each firm, as not all the firms had identifiable marketing managers. The request was that someone who is familiar with the marketing practices of the firm should complete the questionnaire.

The conclusion was that 428 firms had responded online and 378 questionnaires were fully usable.

\section{Results interpretation}

$\mathrm{O}_{2.1}$ Analysis of the managers' vision from the small and medium companies concerning the need for marketing planning

$78 \%$ of the managers from the investigated companies consider as necessary the strategic planning

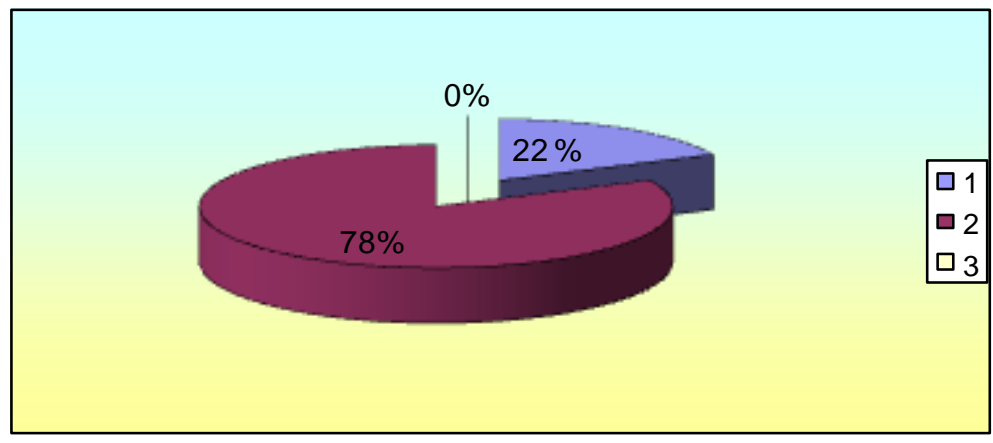

Figure 1. Necessity of using marketing planning

Legend: 1 No 2 Yes 3 Do not know

Hypothesis $\mathrm{H}_{01}$ : The majority of managers from small and medium sized companies questioned do not consider that the marketing strategy is necessary, is not true.

The frequency of planning realization was done:

- at the beginning of the year

- every two years

- some answers referred to when it is necessary or modifications on the market occured

\section{$\mathrm{O}_{2.2} \quad$ Analysis of using the marketing strategy}

Most of those interviewed sustain that they act according to marketing strategies (294 firms). In the case of $78 \%$ of the analyzed firms the marketing strategy is formulated and in the case of $22 \%$ there is no strategic planning. 
A study carried out on 30 firms from the manufacturing industry in the North-West part of Romania, concerning the strategy existence and content, proved that 33,3\% of the studied firms have a formalized ${ }^{13}$ strategy. The determinant role in formulating the strategy in the analyzed firms is played by the general manager. The analysis aims the firm's general strategy and its strategic planning.

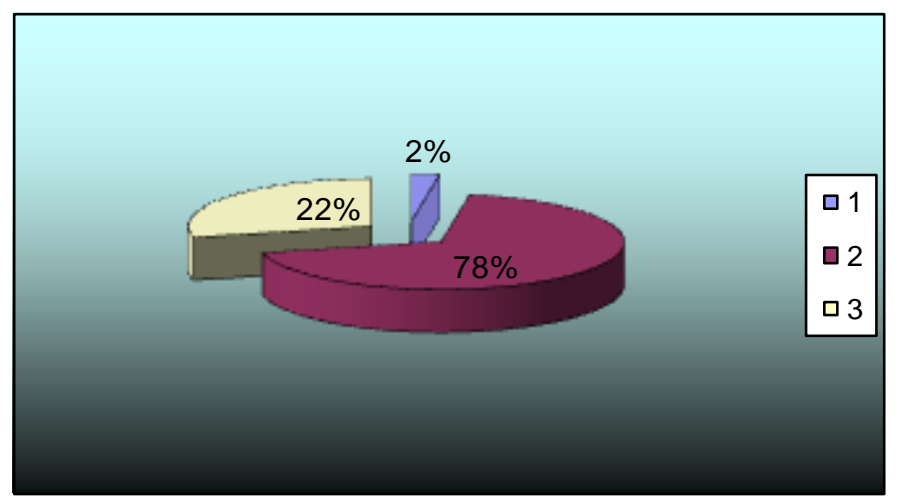

\section{Figure 2 Using marketing strategy in shoes industry}

Legend: 1- at all 2- low 3- high

Hypothesis $\mathrm{H}_{03}$ : Managers do not formulate marketing strategies is not true.

A) Analysis of the existent statistic correlation between the marketing strategy and the legal status

Correlations are significant for $\mathrm{p}<, 05000$

$\mathrm{N}=4$ (number of cases eliminated)

Correlation coefficient is $-0,292$

$\mathrm{p}=, 708$

There are no significant correlations between tese two variables.

B) Analysis of the existent statistic correlation between the startegy usage and CA

Correlations are significant for $\mathrm{p}<, 05000$

$\mathrm{N}=4$ (number of cases eliminated)

Correlation coefficient is 0,881

$\mathrm{p}=, 119$

There is correlation between these two variables but it is not statistically significant as p exceeds the accepted value.

\footnotetext{
${ }^{13}$ Şuteu S., Cândea D., 2005. Cercetare privind existenţa şi conţinutul strategie , în firme româneşti din industria prelucrătoare, Revista de Management şi Inginerie Economică , Vol. 4, Nr.1.
} 


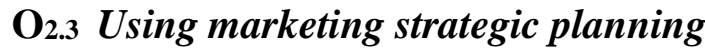

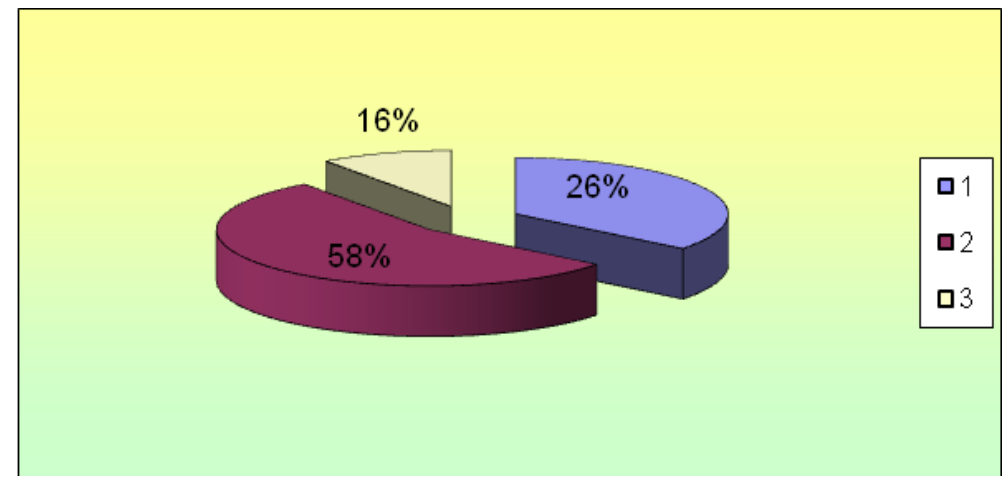

Figure 3 Marketing planning

Legend: 1- no 2- annual plan 3- medium and long term plan

Concerning the marketing plan the results show that $58 \%$ of firms have annual strategic plan and $16 \%$ have medium and long term plan.

a) Analysis of the existent statistic correlation between the startegy usage and CA

Correlations are significant for $\mathrm{p}<, 05000$

$\mathrm{N}=4$ (number of cases eliminated)

Correlation coefficient is 0,932

$\mathrm{p}=, 068$

The relation is a significant one and the correlation is to be taken into account in discussing those two variables.

Table 1

Marketing planning / Turnover

\begin{tabular}{|c|c|c|c|c|c|}
\hline & & & $\begin{array}{l}\text { Marketing } \\
\text { planning }\end{array}$ & & \\
\hline & & No & Annual plan & $\begin{array}{ll}\text { Medium and } \\
\text { long term } \\
\text { plan }\end{array}$ & Total \\
\hline & 100 & 23 & 75 & 4 & 102 \\
\hline \multirow[t]{4}{*}{$\mathrm{CA}$} & $100-1$ & 37 & 125 & 76 & 238 \\
\hline & 1billion 10 & 0 & 18 & 18 & 36 \\
\hline & Over 10 & 0 & 1 & 1 & 2 \\
\hline & Total & 60 & 219 & 99 & 378 \\
\hline
\end{tabular}

D) Analysis of the existent statistic correlation between the marketing strategy and the legal status

Correlations are significant for $<, 05000$

$\mathrm{N}=4$ (number of cases eliminated)

Correlation coefficient is 0,507

$\mathrm{p}=, 493$

The correlation between these variables is not to be taken into account from statistic point of view. 


\section{$\mathbf{O}_{2.4} \quad$ Areas of strategic planning}

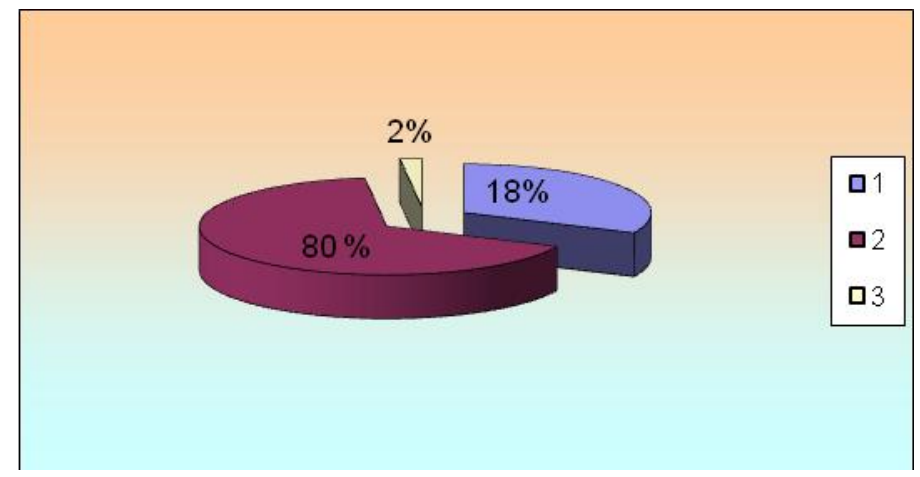

Figure 4 Planning at market segment level

Legend: 1- yes 2- no 3- do not know

Planning at segment level is carried out in the case of $18 \%$ of companies, a very significant rate, namely $80 \%$ do not realize target plans for the aimed market segment.

One can notice that generally speaking, managers are not interested in identifying the target segments, or the consumer behavior.

Hypothesis $\mathrm{H}_{02}$ : Planning at the level of market segment within firms is true.

A) Analysis of the existent statistic correlation between planning for each market segment and $\underline{\text { segmentation }}$

Correlations are significant for $\mathrm{p}<, 05000$

$\mathrm{N}=4$ (number of cases eliminated)

Correlation coefficient is 0,954

$\mathrm{p}=, 046$

The correlation coefficient is approximate maximum and one can state that there is a very close correlation between the market segmentation and the strategic planning for each market segment.

Planning at segment level /Market segmentation

\begin{tabular}{||l|l|l|l|l|l|}
\hline & & & $\begin{array}{l}\text { Segment } \\
\text { Planning }\end{array}$ & & \\
\hline & & Yes & No & Do not know & Total \\
\hline & Yes & 36 & 139 & 1 & 176 \\
\hline \multirow{2}{*}{ Market segmentation } & No & 32 & 166 & 1 & 199 \\
\hline & Do not know & 1 & 1 & 1 & 3 \\
\hline & Total & 69 & 306 & 3 & 378 \\
\hline
\end{tabular}

Only $18 \%$ of companies are using the market segmentation and the strategic planning for each segment.

B ) Analysis of the existent statistic correlation between planning for each market segment and firm's legal status

Correlations are significant for $\mathrm{p}<, 05000$

$\mathrm{N}=4$ (number of cases eliminated)

Correlation coefficient is 0,378

$\mathrm{p}=, 622$ 
There is no correlation.

C) Analysis of the existent statistic correlation between planning for each market segment and CA

Correlations are significant for $\mathrm{p}<, 05000$

$\mathrm{N}=4$ (number of cases eliminated)

Correlation coefficient is 0,959

$\mathrm{p}=, 041$

Table 3

Planning at segment level /Fiscal value

\begin{tabular}{||l|l|l|l|l|l|}
\hline & & & $\begin{array}{l}\text { Segment } \\
\text { Planning }\end{array}$ & & Total \\
\hline & & Yes & No & Do not know & \\
\hline & 100 & 21 & 112 & 2 & 135 \\
\hline FV & $100-1$ & 33 & 186 & 1 & 220 \\
\hline & 1 billion 10 & 20 & 1 & 0 & 21 \\
\hline & over10 & 2 & 0 & 0 & 2 \\
\hline & Total & 76 & 299 & 3 & $\mathbf{3 7 8}$ \\
\hline
\end{tabular}

One can notice that there is a close correlation between planning and the fiscal value.

\section{$\mathbf{O}_{2.5}$ Analysis of the market research usage}

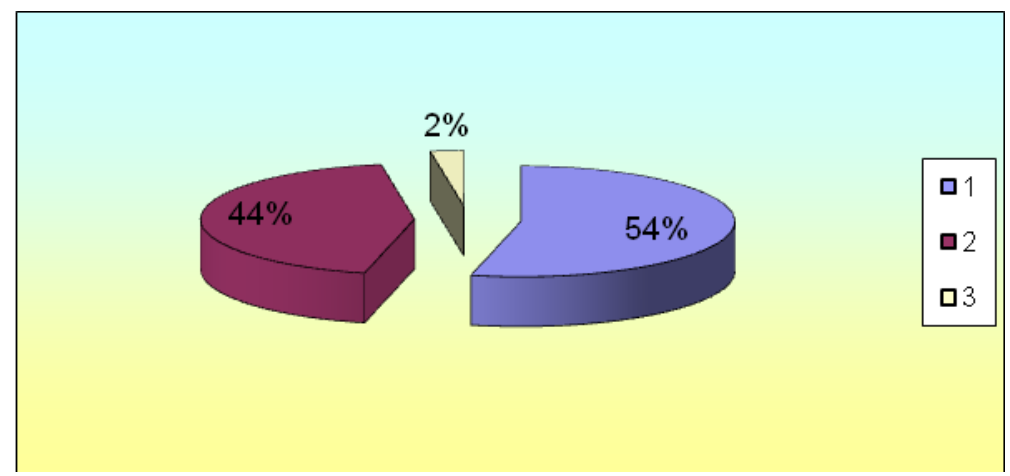

Figure 5 Carrying out the market researches

Legend: 1- yes 2- no 3- do not know

It is encouraging the fact that $53 \%$ of the companies have carried out market researches, but the rate of those which do not use the research is still high, respectively $44 \%$.

A) Analysis of the existent statistic correlation between the market researches and firm's legal $\underline{\text { status }}$

Correlations are significant for $\mathrm{p}<, 05000$

$\mathrm{N}=4$ (number of cases eliminated)

Correlation coefficient is 0,856

$\mathrm{p}=, 144$

The correlation coefficient is appropriate but $\mathrm{p}$ has a too high value.

Statistically these two variables do not have a significant correlation.

B) Analysis of the existent statistic correlation between the marketing research and firm's fiscal value

Correlations are significant for $\mathrm{p}<, 05000$ 
$\mathrm{N}=4$ (number of cases eliminated)

Correlation coefficient is 0,639

$\mathrm{p}=0,361$

There are no statistical correlations between the marketing researches and the firms fiscal value.

\section{O 2.6 Analysis of the marketing activity control}

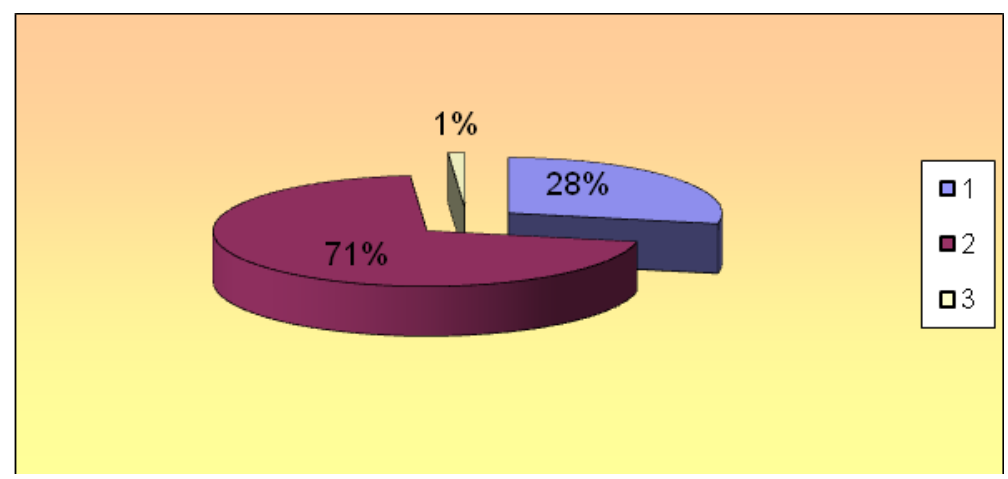

\section{Figure 6 Marketing activity control}

Legend: 1- yes 2- no 3- do not know

The marketing activity control is used $28 \%$.

A) Analysis of the existent statistic correlation between the marketing activity control and the firm's legal status

Correlations are significant for $\mathrm{p}<, 05000$

$\mathrm{N}=4$ (number of cases eliminated)

Correlation coefficient is 0,297

$\mathrm{p}=, 703$

There are no significant correlations between those two variables.

B) Analysis of the existent statistic correlation between the marketing activity control and the firm's fiscal value

Correlations are significant for $\mathrm{p}<, 05000$

$\mathrm{N}=4$ (number of cases eliminated)

Correlation coefficient is 0,973

$\mathrm{p}=, 027$

The relation between those two variables is almost perfect. The correlation coefficient is close to1.

C) Analysis of the existent statistic correlation between the marketing activity control and the legal $\underline{\text { status }}$

Correlations are significant for $\mathrm{p}<, 05000$

$\mathrm{N}=4$ (number of cases eliminated)

Correlation coefficient is 0,297

$\mathrm{p}=, 703$

There are no significant correlations between those two variables.

\section{Data Analysis:}

\begin{tabular}{|l|l|l|}
\hline $\begin{array}{l}\text { Analysis of the correlation } \\
\text { between consulting the } \\
\text { specialists in marketing } \\
\text { and strategies usage }\end{array}$ & $\begin{array}{l}\text { Number of cases excluded 3 } \\
\mathrm{R}=0.98 \\
\mathrm{~T}=0.05\end{array}$ & $\begin{array}{l}\text { Correlation is significant, } \\
\text { the relationship is very } \\
\text { strong. }\end{array}$ \\
\hline Analysis of the correlation & Correlations are significant & Correlation coefficient is \\
\hline
\end{tabular}




\begin{tabular}{|c|c|c|}
\hline $\begin{array}{l}\text { between the number of } \\
\text { marketing staff and the } \\
\text { marketing } \\
\text { usage }\end{array}$ & $\begin{array}{l}\text { for } \mathrm{p}<, 05000 \\
\mathrm{~N}=4 \quad \text { (number of cases } \\
\text { eliminated) } \\
\text { Correlation coefficient is } \\
0,932 \\
\mathrm{p}=, 068\end{array}$ & $\begin{array}{l}\text { good, the relationship is } \\
\text { almost perfect. }\end{array}$ \\
\hline $\begin{array}{l}\text { Analysis of the correlation } \\
\text { between } \\
\text { segmentation and strategic } \\
\text { planning }\end{array}$ & $\begin{array}{l}\mathrm{N}=4 \text { (number of cases } \\
\text { eliminated) } \\
\text { Correlation coefficient is } \\
0,954 \\
\mathrm{p}=, 046\end{array}$ & $\begin{array}{l}\text { Correlation between } \\
\text { variables is almost perfect, } \\
\text { the statistical relation is } \\
\text { significant. }\end{array}$ \\
\hline $\begin{array}{l}\text { Analysis of the correlation } \\
\text { between market } \\
\text { segmentation and strategic } \\
\text { planning usage }\end{array}$ & $\begin{array}{l}\mathrm{N}=4 \text { (number of cases } \\
\text { eliminated) } \\
\text { Correlation coefficient is } \\
0,979 \\
\mathrm{p}=, 021\end{array}$ & $\begin{array}{l}\text { Close relationship between } \\
\text { these two variables. }\end{array}$ \\
\hline
\end{tabular}

\section{Conclusions}

In this current study our aim was to analyze the marketing tactics, namely the strategic planning, market segmentation, correlation between the marketing activities and firms' performances, as well. In this context, we examined both the marketing practices and the associations between practices and performance.

Keeping in mind that the results of our study refer to small and medium sized firms, one can easily notice that strategic marketing planning and market segmentation are those two fundamentals staying at the bottom of practice.

The research in the case of marketing performance for smalls firms can be also applied for larger firms with customers predisposed to contractual and/or repeated purchases.

It can be also mentioned the fact that the managers of small and medium sized firms are using strategic planning as instrument, but this is not correlated to other tools which could supervise the market segmentation, on the one side, or, to marketing activity control, on the other side.

\section{References}

1. Aaker, D.A., 1984. Strategic marketing management, Wiley, Chichester, pp. 11-22.

2. Abrudan I., Lobontiu G., Lobontiu M., 2003. IMM-urile şi managementul lor specific, Ed. Dacia, Cluj-Napoca.

3. Arinze, B., 1991. A Contigency Model of DSS Development Methodology Journal of Management Information Systems, Vol. 8, Nr.1, pp. 149 - 166.

4. Armstrong, J.S., 1988. Strategic planning and forecasting fundamentales, IMEDE, Lausanne, Elveţia.

5. Armstrong, M., 1993. Management techniques, Kogan Page Ltd, London.

6. Bacali L., 2002. Marketing Manual de Inginerie Economică, Ed. Dacia (coord.).

7. Bacali, L., 1998. O abordare de marketing comparat, Economistul, Nr.4, p.6

8. Bansal, A., Kauffman, R., Weitz, R., 1993. Comparing the Modeling Performance of Regression and Neural Networks as Data Quality Varies: A Business Value Approach, Journal of Management Information Systems, Vol.10, Nr.1, pp. 11 - 32

9. Barney, J.B., 1991. Firm resources and sustained competitive advantage, Journal of Management, Nr.17, pp. 99-120 
10. Behrman, N., Perreault, W.Jr, 1992. Measuring the performance of industrial sales persons, Journal of Business Research, Nr.10, pp. 355-700.

11. Birley, S., 1982. Corporate strategy and the small firm, Journal of General Management, Vol.8, Nr. 2, p. 82

12. Buzzell, R.D., 1987. Gale, B.T.,The PIMS Principles: Linking Strategy to Performance, The Free Press, New York.

13. Carson, D., Cromie, S., 1995. Marketing and Entrepreneurship in SMEs, Prentice Hall, London.

14. Chaston, I., 1997. Small firm performance: assessing the interaction between entrepreneurial style and organizational structure, European Journal of Marketing, Vol. 31, Nr. 11/12, pp. 814-831.

15. Hill, J., McGowan, P., A qualitative approachto developing small firm marketing planning competencies, Qualitative Market Research: An International Journal, Vol.2, Nr. 3, 1999, pp. 167-175.

16. Hill, J., McGowan, P., Maclaren, P., 1998. Developing marketing planning skills: combining theoryand practice,' Journal of Marketing Practice:Applied Marketing Science, Vol. 4, Nr. 3, pp. 69-83.

17. Indjejikian, R, 1998. Performance evaluation and compensation research: an agency perspective, Accounting Horizons, pp. 147-580.

18. McDonald, M., 1989. Ten barriers to marketing planning, Journal of Marketing Management, Vol. 5, pp. 1-19.

19. McDonald, M., 1982. The theory and practice of marketing planning for industrial products in international markets, Phd. Thesis, Cranfield University.

20. Robinson, R. B., 1982. Measuring organisational performance in the absence of objective measures: the case of the privately-held firm and conglomerate business unit, Strategic Management Journal, Nr. 5, pp. 252-730. 